\title{
CATHRINE HASSE
}

\section{FRA JOURNALIST TIL „BIG MAMMA“ \\ Om sociale rollers betydning for antropologers datagenerering}

Det er en kold formiddag $\mathrm{i}$ januar måned, og jeg svinger med kurven for at holde varmen. Fra vinduer og døråbninger stirrer de små sortklædte koner, og på pladsen stopper de gamle mænd med tandløse munde og brune kasketter deres snak, idet jeg passerer. Da jeg er kommet forbi, går snakken videre. Ordene,,journalista, journalista danese“ er genkendelige selv på sardisk. Hos købmanden forstummer snakken, da jeg træder ind - men jeg når at høre ordene „tyv“" og ,narkoman“. Både kunder og købmand ser et kort øjeblik forlegne ud. Så spørger købmanden, hvad jeg skal have - og kunderne træder til side, så jeg kan komme frem i køen. Jeg ved, at når jeg træder ud af butikken, vil de igen tale livligt om det tyveri, en af byens tre narkomaner begik i går. Han er afbilledet på forsiden af den lokale avis, men ikke engang min signora vil fortælle mig noget nærmere om episoden.

Det går ikke så godt med mit feltarbejde. Jeg kan ligesom ikke få ,hul igennem“. Det er som om, de har placeret mig i en rolle, jeg ikke kan komme ud af. Det er tydeligt, at folk her er utrygge ved journalister, og det er selvfølgelig også en oplysning, jeg kan registrere. Men hvordan skal jeg indhente relevante data, når de folk, jeg er mest interesseret $\mathrm{i}$ at tale med, er bange for mig?

De spørgsmål stillede jeg mig selv, da jeg i vinteren 1993 for anden gang kom til den italienske landsby Mamoiada, der ligger midt i Barbagiabjergene på Sardinien. Da jeg besøgte Mamoiada nogle måneder tidligere, havde jeg præsenteret mig som journalist. Begrundelsen for mit valg af præsentation var, at jeg, ud over at være antropolog, også er journalist, og det forekom mig på det tidspunkt mere ukompliceret og genkendeligt for mamoiadinerne, at jeg præsenterede mig som journalist snarere end antropolog.

Erfaringen har lært mig noget om andres forventninger til, hvad det betyder at være journalist og antropolog - og disse erfaringer og forventninger har været med til danne mine forestillinger om, hvad det vil sige at tænke og handle som henholdsvis antropolog og journalist. Prototypiske fordomme former en del af vores forståelse af de sociale roller. ${ }^{1}$ Men det gør de nye erfaringer, vi gør os, i mødet med andre også.

Sociale roller er ikke løsrevet fra individet. Deraf følger, at det individuelle kan sætte sit præg på opfattelsen af og fordommene omkring den sociale rolle. Min erfaring fra Mamoiada viser, at jo mere genkendelig ens rolle er i den sociale sammenhæng, jo flere personlige følelser kan komme til udtryk gennem rollen. 
Jeg vil i det følgende vise, hvordan jeg ændrede min sociale rolle fra den frygtede journalist over den fredelige folkloreforsker til den socialt accepterede rolle som tolk og ,big mamma" for den lokale folkloregruppe mamuthones i Mamoiade. Ved hjælp af disse konkrete eksempler vil jeg forsøge at beskrive, hvordan opmærksomhed over for antropologens sociale roller kan have betydning for et feltarbejde. Min opfattelse af ,sociale roller" er inspireret af Martin Hollis (1985), hvilket jeg vil uddybe senere. ${ }^{2}$

\section{Antropologen}

Under mit i alt fem måneder lange feltophold i Mamoiada udfyldte jeg en række forskellige sociale roller i den lokale sammenhæng. Nogle roller blev givet mig som et tilbud, andre blev påført mig som en spændetrøje. Men undervejs i forløbet lærte jeg at udnytte de muligheder, jeg havde for rolleplacering i landsbyen, så jeg fik adgang til de data, jeg ønskede. Jeg vil i denne artikel argumentere for, at lokale sociale roller kan udnyttes i feltarbejdet ud fra følgende tre antagelser:

1. Antropologen indtager altid sociale roller i en lokal kontekst. Disse roller har betydning for, hvordan hun opfattes i en lokal sammenhæng, hvem der bliver hendes naturlige samtalepartnere og dermed for, hvilke data hun får adgang til. Den lokale befolkning kan have en anden forståelse af rollens betydning end antropologen selv (tænk for eksempel på en bistandsantropolog, der opfatter sig selv som repræsentant for en humanitær hjælpeorganisation, mens den lokale befolkning opfatter hende som en geskæftig entreprenør, der ændrer de lokale magtforhold, eller måske tror hun arbejder under dække for at rapportere om deres forhold til de lokale skattemyndigheder).

2. Antropologen kan, ved at være bevidst om de sociale roller hun indtager i henholdsvis egne og befolkningens øjne, i nogen udstrækning nedtone nogle af sine sociale roller (her kan et eksempel være den kvindelige antropolog med børn, der vælger at lade børnene blive hjemme for ikke at være låst fast i en social rolle som ,mor" i den lokale kontekst). Antropologen kan også forsøge at betone visse rolleplaceringer fremfor andre. (Ønsker antropologen for eksempel kontakt med de lokale fiskere, kan hun benytte sin eventuelle viden som lystfisker eller sejler.)

3. Sociale roller er altid specifikke i forhold til en konkret, lokal sammenhæng. Antropologen kan være åben over for alle de sociale roller, som lokalbefolkningen giver hende mulighed for at indtage (hvad enten de selv tilbyder det eller ej). Her kan være tale om sociale roller, der ligger fjernt fra antropologens egen selvforståelse, men som alligevel er inden for hendes sociale muligheder i den lokale kontekst (et eksempel kan være, at antropologen, der er en kvinde, accepterer at blive en af den lokale herskers 200 koner).

\section{Den sociale maske}

Mit eget eksempel fra Mamoiada, som jeg skal vende tilbage til, viser, at det er muligt at veksle mellem flere sociale roller og forsøge at skaffe sig adgang til visse typer antropologiske data ved at udnytte forskellige rolleplaceringer.

Mange antropologer berører i deres arbejder de sociale roller, de har været placeret i, i en lokal sammenhæng. Nogle beskriver, hvordan de bliver adopteret som høvdingens 
„datter“, andre, som Turnbull hos mbuti-folket, betragtes som børn, der skal oplæres, andre bliver helbredere, fødselshjælpere og lignende.

Kirsten Hastrup er en af de antropologer, der har arbejdet med social rolleplacering i en lokal kontekst som islandsk fiskerpige, fårehyrde og malkepige - ofte i en sådan grad, at hun har oplevet et identitetsskifte (Hastrup 1990). Hun er, når man læser om hendes erfaringer fra Island, meget bevidst om såvel påtagede som medfødte - og såvel pålagte som selvvalgte - sociale roller.

I en artikel om en islandsk vædderudstilling møder læseren et skisma, der er en Antigone værdigt. ${ }^{3}$ Hastrup er malkepige, der malker og sender køerne afsted til græsning. Herefter tager bonden til vædderudstilling, men malkepigen inviteres ikke med. Denne særlige malkepige oplever dette som et savn, fordi hun også er antropolog. Hastrup bander over sin malkepigestatus, men en ung pige på stedet forstår, at Hastrup er antropolog - og kører hende til udstillingen. Og her oplever Hastrup i en hørm af væddere og maskulin seksualitet, at der er tale om et „kun for mænd/væddere“-møde, som hun ikke passer ind i (Hastrup 1989:72). I en anden beskrivelse gør Hastrup opmærksom på, at hun har overgivet sig til sin rolle som malkepige, at hun har internaliseret et rum, der følger andre spilleregler end hendes sædvanlige (Hastrup 1990:48).

Der er, forekommer det mig, et problem i disse rolleskift mellem malkepige og antropolog, mellem to sociale roller, der ligger langt fra hinanden. Problemet er ikke, at det ikke kan lade sig gøre at skifte rolle. Men at der mangler en forklaring på, hvordan antropologen kan hente data fra en selverfaret oplevelse af at være malkepige, samtidig med at hun kan deltage i en vædderudstilling som antropolog. Det rejser en række spørgsmål. Hvordan har antropologen opnået den uvante rolle som malkepige? Er internaliseringen uafhængig af de øvrige personer i den lokale kontekst? Er malkepigen en social maske, som antropologen kan tage af og på?

Set i dette perspektiv kan sociale roller anskues som masker, vi kan vælge at tage af og på ud fra strategiske overvejelser, vores egne opfattelser af rollerne eller fordomme om, hvordan andre opfatter dem. Der antages, med andre ord, at være et selv bag masken, der vælger, vrager og vurderer de muligheder, de sociale roller giver. Også når det gælder om at hente epistemologiske data fra en anden virkelighed.

\section{Den sociale person}

Men hvilket selv, spørger Martin Hollis (1985:227), kan adskilles fra social position og de sociale roller? Hollis besvarer selv spørgsmålet: De sociale roller kan ikke adskilles fra en persons identitet. I en pragmatisk virkelighed oplever vi hverken os selv eller andre som gemt bag sociale masker i formummede rollespil.

De sociale roller er en del af det handlende, tænkende menneske, der kan lære af de erfaringer, det gør sig - blandt andet med egne og andres sociale roller. Vores handlinger er ikke drevet af et præfabrikeret indre selv. De udspringer af vores selv, fordi de udføres af den samme sociale aktør (Hollis 1985:229).

Mennesker er med andre ord personer, blandt andet fordi vi gør vores egne erfaringer gennem og med sociale roller i sociale systemer. Når jeg optræder i min egenskab af journalist i Mamoiada, er jeg i en vis forstand iklædt en social maske - men en maske, der er en del af min person. Ordet ,person“ er etymologisk koblet til rollespil og masker. Det 
kommer af det latinske ,per sonare“, at ,lyde igennem“, hvilket igen henviser til skuespillerens stemme, der lyder gennem masken (Lommel 1981:198). Men der er ikke tale om en maske, der blot repræsenterer. En maske, man frit kan iføre sig, når man ønsker at spille en bestemt social rolle, og kastes bort efter brugen. Jeg er journalist, og rollen bedømmes erfaringsmæssigt af andre, ligesom jeg selv handler og tænker ud fra mine erfaringer som journalist. Martin Hollis' tilgang gør det muligt at se, at vi kan handle individuelt, ikkedetermineret gennem vores sociale roller. Vi lærer og erfarer gennem de sociale roller, vi møder og selv antager. De sociale roller skaber og begrænser muligheder, hvilket vi erfarer og reagerer på som intelligente væsner i en konstant proces (Hollis 1985: 231).

En social rolle er derfor ikke en repræsentation. Det er den del af selvet, vi ,lyder gennem“. Hver enkelt af os har mulighed for at indtage mange sociale roller. De behøver ikke at opleves som modstridende. Men vi vil såvel i andres som i egne øjne handle gennem sociale roller. De kan aldrig helt vælges fra. Kommer vi i konflikt med vores forskellige sociale roller, er det vores erfaring, der gør det muligt for os at vælge. Men valget er ikke ubegrænset. Vi er netop ikke skuespillere, der frit kan påtage os sociale masker. Jeg kan for eksempel ikke selv med min bedste vilje vælge den sociale rolle „far" til et studie i børns forhold til fædre og heller ikke til et studie i, hvordan det opleves at være far.

Der kan naturligvis fremkomme antropologiske data, ved at antropologen ikke udfylder sin lokale rolle godt nok. Antropologer kan lære meget ved at begå fejl i en lokal sammenhæng. Det er blot vigtigt at gøre opmærksom på, at det er som „fejl“", ikke ,indforståethed“, at denne viden er opnået. Og hvis noget formidles som ,indforstået“ viden, skal adgangen til denne viden sandsynliggøres. Hvis den sociale rolle, antropologen har, i de lokales øjne slet ikke er ,fårehyrde“ (som antropologen måske forstiller sig) men ,en udlænding, der leger fårehyrde", vil hendes data bære præg af misforholdet mellem hendes opfattelse og fårehyrdernes opfattelse af den rolle, hun spiller i en lokal sammenhæng.

\section{Journalisten}

I Mamoiada gik det, under mit andet besøg i landsbyen, op for mig, at min sociale rolle som journalist begrænsede mine muligheder for at få adgang til de data, jeg ønskede.

Jeg var i første omgang kommet til Mamoiada, fordi jeg var i gang med en journalistisk research som grundlag for mit senere feltarbejde (Hasse 1994, 1995). ${ }^{4}$ Fra en dansk veninde havde jeg hørt, at der skulle være nogle interessante maskeoptog, som var knyttet til karnevallet og nogle kristne fester på Sardinien. Det var disse optog, jeg var gået i gang med at samle oplysninger om.

Hver januar og februar går 12 mænd iført sorte træmasker, skindkofter og tunge kæder af koklokker gennem byens gader. Mændene er organiseret i en klub, og billeder af mændene i optoget bliver brugt som byens officielle ansigt udadtil. Mit projekt kunne, forestillede jeg mig, tage udgangspunkt i de sociale relationer, der var knyttet til det bestemte maskeoptog og de følelser, det fremkaldte hos såvel deltagerne som folk fra landsbyen. For at få denne viden ønskede jeg så vidt muligt at blive integreret i landsbylivet. Jeg havde på det tidspunkt ikke gjort mig nærmere overvejelser over, hvordan jeg kunne opnå integration.

En dag i begyndelsen af mit andet ophold fulgte jeg gruppen af mænd tilbage til det klublokale, hvor de opbevarer de rituelle skinddragter, maskerne og de store bronzeklok- 
ker mellem optogene. Jeg blev glad, da Antonello - en af de mest engagerede mænd i gruppen - tillod mig at komme med nogle forsigtige spørgsmål om udstyret. Opmuntret af min succes spurgte jeg, om jeg ikke måtte besøge ham i hans hjem for at lave et interview om udstyrets betydning. Reaktionen kom øjeblikkelig. Han rystede voldsomt på hovedet og så på mig, som om jeg havde sagt noget forfærdeligt dumt. ,Det her må du lære, hvis du vil snakke med os“, sagde han og vendte sig for at gå, ,,man interviewer ikke sine venner". ${ }^{5}$ Den dag forstod jeg, at jeg blev nødt til at ændre min sociale rolle. Jeg kunne ikke være „la journalista“, hvis jeg skulle opnå folks tillid.

Først nu lang tid efter er det gået op for mig, hvordan jeg, længe inden jeg kom til Mamoiada for anden gang, havde vægtet mine sociale roller. Jeg havde for eksempel valgt at lade min datter blive hjemme under andet besøg, fordi jeg var interesseret $\mathrm{i}$, hvordan mændene oplevede optoget. En lokal social rolle som „mor“ ville have gjort det meget svært for mig at få adgang til mændenes verden i det kønsopdelte samfund. Ved første besøg var jeg blevet introduceret for familier, der selv havde børn, men jeg havde ikke kunnet deltage i mændenes sammenkomster. Under mit andet besøg kunne jeg følge med mændene rundt på deres udflugter, mandefester i klubben og følge optogene uden at skulle bekymre mig om et dårligt ry som ,ravnemoder“.

Efter min oplevelse med Antonello, nedtonede jeg endnu en social rolle.

\section{Folkloreforskeren}

Da jeg først havde indset, at journalistrollen var en hæmsko for mit feltarbejde i Mamoiada, afstod jeg fra alle metoder, der kunne forbinde mig med journalistik: notetagning, interview, en pågående måde at stille spørgsmål på og faste aftaler om indhentning af oplysninger. Samtidig overvejede jeg, hvilke muligheder jeg havde for at opnå en mere socialt acceptabel rolle i landsbyen. Ud over at fjerne folks mistillid til min person, skulle den gøre det nemmere for mig at færdes blandt almindelige mennesker, hvor min journalistrolle i den lokale selvforståelse indtil nu naturligt havde bragt mig i kontakt med byens spidser.

Det ville være svært at få arbejde i byen. Der var i forvejen stor arbejdsløshed. Selv som butiksmedhjælper ville jeg kunne risikere at støde folk fra mig ved at tage brødet ud af munden på byens egne børn. Meget andet arbejde blev udført som vennetjenester i et „give og tage“-system. Jeg besluttede mig til at satse på at give gratis undervisning i engelsk - noget mændene i klubben havde ladet mig forstå, de kunne være interesserede i. Men jeg nåede ikke engang at prøve at føre rollen ud i livet. Et par forsigtige forespørgsler afslørede, at folk ville anse mig for en tåbe, hvis jeg underviste gratis - og at de i øvrigt ville anse det for urimeligt, hvis de skulle betale for det, da jeg jo ikke havde noget diplom som engelsklærer. Desuden ville kvinderne nok heller ikke lade deres mænd gå til enetimer hos mig.

Det var en bibliotekar i en nærliggende købstad, der omsider gav mig mulighed for en anvendelig tilgang. Jeg opdagede et lille bibliotek, der havde specialiseret sig i egnens historie og havde mange bøger om de lokale maskeoptog. Selv om det var de levende mennesker i landsbyen, jeg interesserede mig for, og netop ikke den folkloreforskning, der fandtes på biblioteket, fandt jeg her en åbning til lokalsamfundet i form af den sociale rolle som folkloreforsker. Den rolle kendte alle i landsbyen, for der har længe været 
mange både lokale og udefrakommende folkloreforskere på Sardinien. Modsat rollen som journalist var det en socialt acceptabel og ufarlig rolle. Som et led i mine forberedelser til rollen besøgte jeg en lokal folkloreforsker i en nærliggende landsby for at høre, hvordan hun arbejdede, og af hende lærte jeg også, hvilken type spørgsmål folkloreforskere stiller.

$\mathrm{Nu}$ betonede jeg ved enhver given lejlighed min interesse for folklore. Selve ordet blev en nøgle, der åbnede mange af de døre, som hidtil havde været lukkede for mig. Rollen var en tilpasning og finpudsning af min sociale rolle som antropolog, da antropologer, i det omfang de overhovedet kendes i den lokale sammenhæng, nemt kan opfattes som europæiske folkelivsforskere. Selv om rollen var mig fremmed, var den, modsat en rolle som for eksempel fårehyrde, en del af mig og derfor troværdig for både mig selv og de andre.

Jeg havde i begyndelsen besluttet, at jeg ville tilbringe al min tid i landsbyen. Men min nye rolle medførte, at jeg måtte ændre taktik. Nu var jeg (eller blev gradvis i løbet af et par uger) folkloreforsker, og folkloreforskere læser sig til en stor del af deres viden. Derfor var det naturligt for mig at have ,,arbejdstid“ på biblioteket i Nuoro. Det medførte, at jeg fik tilbudt kørelejlighed de ca. 20 kilometer frem og tilbage. Jeg blev nu en af de mange fra landsbyen, der ,kørte med“ nogle andre, når de skulle til byen for at arbejde.

På turen ud og hjem småsnakkede vi om løst og fast - blandt andet om de mange stærke følelser, der var bundet op mellem mændene i maskeklubben og en anden tilsvarende klub. Efterhånden fandt jeg gennem vores småsnak også ud af, at angsten for journalister til dels bundede i landsbyens kollektive skam over en lokal vendetta, der i gennemsnit havde kostet et liv om året de seneste 50 år.

Når jeg kom hjem fra ,,arbejdet" i Nuoro, havde jeg status som byens andre udearbejdende. Min signora spurgte bekymret, om jeg var træt, mens hun småsludrede om dagens begivenheder. Jeg fik nye venner, der ikke hørte til blandt byens spidser. De kom efter arbejdstid for at hente mig, så vi kunne glemme arbejdet og more os. Det havde jeg lige så meget behov for som de efter den lange arbejdsdag. Jeg kunne deltage og stille alle de spørgsmål, jeg lystede - så længe de havde en eller anden relation til det, jeg efterhånden opdagede, de lokale forbandt med folklore. Jeg erfarede, hvad ,folkloreforsker“ betød i en lokal sammenhæng, hvilke døre der åbnede sig. Jeg lærte at handle og tænke som en forkloreforsker og blev gradvist et med min rolle. Da min rolle socialt set var troværdig, gav det mulighed for en langt tættere kontakt til folk i byen, og der opstod flere og mere personlige følelser mellem dem og mig.

\section{Laurettos kniv}

Mine erfaringer i Mamoiada viser, at jo mere de lokale folk accepterede min rolle som hørende hjemme i deres virkelighed, og jeg accepterede den rolle, de placerede mig i, jo lettere var det for mig at ,lyde igennem“ rollen.

Jeg var nu blevet accepteret som folkloreforsker. Ulempen ved denne rolle var dog, at den til en vis grad gjorde det svært for mig at deltage i gruppens liv, når der ikke var tale om fester eller noget, der kunne forbindes med folklore. Gruppens medlemsmøder, deres interne skænderier, venskaber og diskussioner havde jeg fortsat ikke adgang til. Her var min sociale rolle som kvinde også en hindring. 
Det var først, da jeg greb en chance, de gav mig, for at ændre rolle endnu engang, at jeg fik mulighed for at følge mændene på tæt hold. Endda både dag og nat $\mathrm{i}$ en hel uge.

Gruppen af mamuthones skulle til England for at deltage i en folklorefestival i Llangolen i Wales. Da jeg en dag talte med den uofficielle leder af gruppen, Giannino, udtrykte han bekymring for, hvordan det skulle gå dem på turen. Han var den eneste med kendskab til engelsk, men over for mig - der jo havde tilbudt mig som engelsklærer - ville han godt indrømme, at hans kendskab til sproget var mangelfuldt. Jeg greb bolden i luften. Jeg havde jo - i min egenskab af folkloreforsker - tænkt på, at det kunne være spændende at opleve folklorefestivalen. Jeg understregede diskret mit kendskab til engelsk. „Så kan du jo tage med som vores tolk“, fastslog han, som jeg havde håbet (og han planlagt?), og på den måde fik jeg endnu en social rolle.

Jeg kørte ud fra Mamoiada i en bus fuld af mænd, drenge, nogle helt unge piger og en enkelt anden bekymret voksen kvinde, Angela. Da bussen fuld af hylende båthorn, sort sardisk vin i strømme og søskendeparret Puggionis klagende sange for fuldt drøn på højtalerne slingrede op ad vejen mod Nuoro, var jeg endnu ikke klar over, at jeg ud over at tolke, ville få tildelt en anden meget typisk italiensk social rolle på turen. Rollen som ,big mamma“. Når vi gjorde holdt ved rastepladserne, hjalp alle til med at brede papirduge ud over grønsværen, hente brød, skinker, grønsager og vindunke. Men det blev snart naturligt, at det var Angela og mig, der stod for at organisere det praktiske. I England blev det, på grund af sproget, i høj grad mig, der stod for at skaffe senge, spisebilletter og brusekabiner til gruppen, der til gengæld hev mig helt ind i fællesskabet. De sang sange til mig og Angela, kaldte os begge „mamma“ og behandlede os med al den respekt, italienske mænd kan udvise for deres mødre. I den forbindelse var fraværet af visse handlinger og tilråb også med til at definere rollen for mig. Som alle lyshårede kvinder ved, føles det, som om italienske mænd har et $\mathrm{i}$ blodet liggende behov for at komme med tilråb og seksuelle tilbud. Men på denne tur var jeg totalt fredet, skønt jeg ind i mellem mærkede de varme følelser bølge ind over mig fra ,mine drenge“ - som jeg rent faktisk begyndte at kalde dem for mig selv.

På skibet på vejen hjem blev Lauretto meget søsyg. Fordi jeg følte mig ansvarlig for ham, var det naturligt for mig at sidde med ham på en bænk, holde ham på panden, hente frisk vand og endog synge lidt for ham. Alt dette ville have været helt utænkeligt for såvel ham som for mig selv blot otte dage tidligere.

Jeg var omsider i en position, hvor jeg havde noget at give; både ægte følelser, som rollen havde givet mig mulighed for at have (og jeg havde oprigtigt medlidenhed med den søsyge mand, men ville nok ikke have bekymret mig så meget, hvis jeg blot havde deltaget som folkloreforsker) og konkret hjælp. Resultatet var, at Lauretto kom på besøg med en vennegave, da vi var kommet hjem. Han takkede mig, som folk i landsbyen havde for vane - og gav mig så en kniv. Kniven var ikke en, man ville give til en ,mamma“. Det var en sort mandekniv med et skarpt blad af stål. Alle mændene i gruppen bar lignende knive, som de brugte, når de tog på udflugter i bjergene, skar fennikel ud foran bålet med pattegrisen eller brødet ved bordet. Det var den bedste gave, han kunne have givet mig. Med den viste han mig, at han vidste, jeg ikke mere blot var en prototypisk, journalist“, ,folkloreforsker“, ,tolk“ eller for den sags skyld en ,mamma“.

Tilbage i landsbyen var jeg folkloreforskeren, men min rolle havde fået en ny mere menneskelig dimension. Der var gennem min ,mamma“-rolle skabt mulighed for gode følelser mellem os. Disse følelser blev bibeholdt, da jeg var tilbage som folkloreinteres- 
seret forsker i landsbyen. Min distance til mændene i gruppen var formindsket, og med kniven i hånden var jeg nu lidt mere en del af deres følelsesmæssige fællesskab. Kort efter løb mine penge ud, og jeg måtte vende hjem. Desværre. For netop på dette tidspunkt havde jeg flere muligheder for at få adgang til de følelsesmæssige data, jeg var interesseret i, end nogensinde før. Hvilket bare viser, at antropologisk metode frem for alt andet også handler om tid.

\section{Metode i tilbageblik}

I antropologien gør det særlige sig gældende, at data ofte erkendes retrospektivt. Heraf følger, at metode også gør det. Vi går ud med forestillinger om at skulle indsamle data via interview, household surveys, spørgeskemaer, genealogier og optællinger. Men det ender ofte ved skrivepulten med, at vores mest værdifulde oplysninger stammer fra andre afledte kanaler. Det antropologiske felt lader sig ikke så let indramme af firkantede metodiske tilgange.

Det er min antagelse, at netop social rolleplacering generelt har stor betydning for fremkomsten af antropologiske data, hvad enten der er tale om et bevidst eller ubevidst metodisk valg fra antropologens side. De sociale roller er derfor altid vigtige for antropologens muligheder for at skaffe sig data, men man kan måske først tale om en metode, når man bevidst forsøger at ændre sin sociale rolle.

Vi kan se på adgangen til data via sociale roller på tre måder:

1) Via vores sociale roller får vi adgang til bestemte miljøer og bestemte personer, som vi herefter har mulighed for at indhente data fra.

2) Sociale roller kan give adgang til nye følelsesmæssige erfaringer - på lokale præmisser.

3) Endelig kan det at indtage sociale roller i en lokal kontekst være datagenererende i sig selv.

Jeg var fra starten interesseret i maskeoptogets sociale betydning og i de følelser, der var knyttet til det. Skønt jeg opnåede en rolle, der gav mulighed for social accept, betød det ikke, at jeg nødvendigvis følte det samme for maskeoptoget som andre i landsbyen. Men ved at arbejde mig igennem en række forskellige sociale roller med dertil hørende fordomme, lykkedes det mig at finde et udgangspunkt, hvor jeg blev lidt mere menneskelig i den lokale kontekst.

Set retrospektivt kan jeg forsøge at efterspore, hvordan det ved en konkret indsats lykkedes at ændre min rolle fra journalist til en mere socialt acceptabel rolle.

Spørgsmålet er, om denne tilgang kan opfattes som en egentlig metode. Der er jo tale om mine personlige rollemuligheder (fordi jeg tilfældigvis både er journalist og kvinde ud over at være antropolog). Men rollerne er kun personlige i den forstand, Martin Hollis taler om. At være i besiddelse af sociale roller er i sig selv ikke en enestående egenskab. Selv om rollerne kan være forskellige fra person til person, har vi alle et stort repertoire af sociale roller, som vi har mulighed for at ,lyde gennem“, og som vi kan fokusere på i større eller mindre grad.

Alt handler ikke om sociale roller. Personlig følelsesmæssig erfaring er for eksempel, hvordan den end er opnået, også betydningsfuld. Renato Rosaldo (1984) har beskrevet, hvordan en større personlig erfaring på det følelsesmæssige område gjorde ham i 
stand til at tolke sine antropologiske data på en ny måde. Men social rolleplacering er et centralt og uomgængeligt vilkår - også for antropologer. Vi kan vælge at opfatte rollen som et redskab. Rollen skal være socialt troværdig og kan kun vælges på de lokale præmisser. Vores roller giver mulighed for adgang til bestemte sociale miljøer og dermed bestemte data. Vi får viden gennem de personlige erfaringer, vi gør os, når vi ,lyder gennem" rollen.

Men jeg mener ikke, som det ses i min brug af Martin Hollis, vi har et frit valg af sociale roller. Vi kan kun spille på de roller, der er knyttet eller kan knyttes til vores person i den givne sociale kontekst.

\section{Sociale roller og data}

Bestemte sociale roller giver adgang til bestemte data. Ligesom et spørgeskema gør det. Adgangen er dog betinget af nogle faktorer, der kobler de personlige kvaliteter med de lokale muligheder for at få adgang til særlige typer af data. Jo længere jeg var i Mamoiada, jo mere kunne jeg inderliggøre min sociale rolle og gøre den til en del af mig. Jeg påførte med tiden min rolle som folkloreforsker nogle personlige kvaliteter, rollen ikke havde i forvejen. Hvor den sociale rolle i starten hovedsagelig bestod af lokale sociale fordomme, forandredes den i mødet med det personlige individ - og i mit tilfælde også af koblingen mellem flere forskellige sociale roller. I landsbyen var jeg først helt distanceret fra de personer, jeg ønskede data fra. Som journalist var det spidserne, der var mine naturlige samtalepartnere. Som folkloreforsker kom jeg tættere på mine kilder til data. Som ,mamma“ i England opnåede jeg respekt, selv om kvinderollen spærrede for min deltagelse i mændenes klubliv. Men tilbage i landsbyen var min sociale rolle som folkloreforsker blevet beriget med den respekt, jeg havde opnået som ,mamma“ - og jeg var anerkendt som en person, der kunne give og tage som de andre i landsbyen.

Jeg ønskede blandt andet data om følelser. Ved at gribe de forhåndenværende muligheder fik jeg en social position, der gjorde det muligt for mig at give og derved også modtage følelser. Havde jeg ønsket data om, hvordan medierne lægges for had, skulle jeg have beholdt min journalistrolle. ${ }^{6}$

Antropologer er ikke ens. Vi kan ikke antage et på forhånd fastlagt sæt af sociale roller. Vi har forskellige muligheder og følgelig også forskellige begrænsninger. Sociale kontekster giver derfor antropologer forskellige muligheder for at „lyde gennem“ lokale sociale roller. Men hvad enten der er tale om et bevidst ønske om adgang til en bestemt type data eller ej, er alle antropologer udstyret med et sæt sociale roller, der kan benyttes mere eller mindre godt i den lokale sammenhæng. 


\section{Noter}

1) Vores opfattelser af (fordomme omkring) de sociale roller ændres konstant i mødet med nye varianter af rollerne. Jeg mener derfor ikke, at sociale roller bør opfattes som fikserede „subjektpositionerende“ kategorier, i forhold til et fragmenteret selv, som Dorinne Kondo (1990) beskriver det. Uanset hvor mange sociale roller (eller subjektpositioner) vi er i stand til at indtage eller møde, kan vi opleve os selv som hele mennesker. Jeg er derfor enig med Peter Hervik (1994) i, at det er nødvendigt at medtænke såvel eksternalisering som internalisering i studiet af de sociale roller.

2) Martin Hollis' tilgang til en beskrivelse af sociale roller udspringer af en diskussion af Marcel Mauss' „A category of the human mind: the notion of person,“ (Mauss 1985). Hollis sætter her en analytisk tilgang til personbegrebet op mod Mauss' historiske gennemgang af selvets udviklingshistorie. For Martin Hollis kan selvet, og de valg individet handler ud fra, ikke fuldkommen adskilles fra vores sociale roller.

3) Som eksempel på denne problematik kan henvises til den græske tragediefigur Antigone, der står splittet mellem sin rolle som søster (der bør begrave sin elskede bror Polyneikes) og lydig undersåt (der har forbud fra kong Kreon mod at begrave oprøreren Polyneikes). Det er også denne skikkelse, Martin Hollis tager som udgangspunkt for sin diskussion af sociale roller (Hollis 1985).

4) For en nærmere gennemgang af brug af journalistiske metoder (herunder research-spørgsmål) i mit feltarbejde se „Brainstorm over Zu Urcu“ (Hasse 1995).

5) Først langt senere kunne jeg forstå, at i Mamoiada bliver man udelukkende accepteret i de sociale sammenhænge i landsbyen, hvis man kan kalde sig en „,ven“. Hvis ikke vil man blive kategoriseret som ,uven“. Der er ingen mellemvej.

6) Havde jeg derimod ønsket viden om, hvordan befolkningen ser på medierne, skulle jeg netop ikke have været journalist, da det kun ville have givet adgang til overfladehadet, men lukket for tilgangen til en dybere lokal forståelse.

\section{Litteratur}

Hasse, Cathrine

1994 Mamuthones. Speciale indleveret til kandidateksamen i antropologi. Københavns Universitet: Institut for Antropologi.

Brainstorm over Zu Urcu. Upubliceret manuskript.

Hastrup, Kirsten

1989 Mandligt og Kvindeligt: kønnets betydning i islandsk kultur. Kirsten Ramløv og Kirsten Hastrup (eds.). Kulturanalyse: fortolkningens forløb i antropologien.

København: Akademisk Forlag

Hastrup, Kirsten

1990 The Ethnographic Present: A reinvention. Cultural Anthropology 5(1):45-61.

Hervik, Peter

1994

Lived Identity, Subjectivity And Moral Understandings: Agency of Three Maya women. Paper delivered at the 93rd Annual meeting of the American Anthropological Association, Atlanta, Georgia.

Hollis, Martin

1985 Of Masks and Men. I: The Category of the Person, Cambridge University Press. 
Kondo, Dorinne

1990 Crafting Selves. Chicago \& London: University of Chicago Press.

Lommel, Andreas

$1981 \quad$ Masks - their meaning and their function. London.

Mauss, Marcel

1985 [1938] A Category of the Human Mind: the notion of person, the notion of self. I: The Category of the Person. Cambridge: Cambridge University Press.

Rosaldo, Renato

1994 Grief and the Headhunters Rage. E.M. Bruner (ed.) I: Text, Play and Story. Washington: The American Ethnological Society. 
